\title{
Viewpoint: \\ Synthesis, range management science, and the Journal of Range Management
}

\author{
DAVID L. SCARNECCHIA
}

Author is Associate Professor, Department of Natural Resource Sciences, Washington State University, Pullman, Wash., 99164-6410, and Book Review Editor, Journal of Range Management.

\begin{abstract}
This paper analyzes the kinds of publications that are currently accepted by the Journal of Range Management, and in view of the evolving identity of range science, proposes a review of the those kinds of papers by the Editorial Board. The paper explores the kinds of papers that would help the Journal in identifying and developing range management science. It suggests a modified emphasis directed at increasing conceptual creativity, and developing explicit, integrative linkages and communications of range management science. In practice, this revision involves increased publication of synthesis papers, and increased emphasis of synthesis in the Journal's publications in general. Major benefits to the Journal would likely be increased diversity of published papers, broader professional diversity of authorship, increased readership, and increased effectiveness in serving and encouraging range management science.
\end{abstract}

Key Words: synthesis, publications, editorial philosophy, Society for Range Management

This paper is mostly about the design of the publication philosophy and a publication plan for the Journal of Range Management $(J R M)$. It examines the kinds of papers the Journal has published, is currently publishing, and should publish. Design of the philosophy and publication plan is achieved through a process familiar to range management scientists and range managers. That process involves designing and developing a plan to achieve multiple objectives in an environment of multiple, evolving, and uncertain variables.

This paper implores a broadened concept of range science as a diverse management science, i.e., as range management science. It encourages an heuristic management science philosophy that can accommodate and use diverse kinds of research. It envisions range management science largely as a science of linkages and communications of multiple kinds. The answers that this paper searches for are, like range management science itself, found more in the minds of people of the present and future than in the artifacts of the past. So the past is not the paper's focus. But the design of the philosophy and plan it presents are based on a desire for evolution of the Journal of Range Management, an evolution served well by an examination of what, in the short history of range science, might be considered

\section{Ancient History}

The Journal of Range Management, flagship publication of the Society for Range Management, was first published in 1948 by the then American Society of Range Management. The papers

\section{Resumen}

Este articulo analiza los tipos de publicaciones que actualmente están siendo aceptadas por Journal of Range Management, y en vista de la identidad evolucionante de la ciencia de pastizales, propone una revisión de esos tipos de artículos por el Comité Editorial. El artículo explora los tipos de artículos que ayudarían al Journal a identificar y desarrollar la ciencia de manejo de pastizales. Sugiere y un énfasis modificado dirigido a incrementar la creatividad conceptual y a desarrollar enlaces integradores y explícitos y comunicaciones de la ciencia de manejo de pastizales. En práctica, esta revisión involucra un aumento de la publicación de artículos sintetizadores e incrementa el énfasis de síntesis de las publicaciones del Journal. Los mayores beneficios para el Journal, probablemente serían, una mayor diversidad de los artículos publicados, una diversidad profesional mas amplia de autoría, más lectores y un aumento en la efectividad en servir y promover la ciencia de manejo de pastizales.

published in the first several years of the Journal, among them some classics, were early attempts to formalize a management art into some kind of science by applying scientific methodologies, and to communicate it effectively. The publications were diverse. Some analyzed management problems or issues of the times. Many papers of this kind would later be published in newsletter media such as the current Member Resource News. Some publications were explanations of management art and lacked the rigor or formality of experimental science. In later years (after 1976), papers of this kind were often published in Rangelands.

Among the papers of those early years, some of the more conspicuous were ones that presented generalized conceptual or philosophical approaches for management or assessment of rangelands and range livestock systems. Such papers included Milestones in Range Management by Robert S. Campbell (1948), Field Comments on the Range Condition Method of Forage Survey by R. R. Humphrey (1949), Condition and Management of Range Land Based on Quantitative Ecology by E. J. Dyksterhuis (1949), and Estimating Perennial Grass Utilization on Semidesert Cattle Ranges by Percentage of Ungrazed Plants by M. E. Roach (1950). Three of these papers were among 18 noted by the graduate class of McClaren (2000) as among the 5 most important articles in the history of the Journal of Range Management. These early conceptual papers are the early stirrings of a nascent range management science from the experiential art from the minds of these early researchers.

Looking back on the first 2 years of the Journal of Range Management, I am impressed by 2 features. First, even though papers such as the ones cited above are, in many respects, ancient 
history, the approaches they offered have only most gradually, sporadically, or locally been succeeded by more sophisticated, integrative, or generalized approaches. Moreover, the Journal of Range Management has not always been the outlet for these subsequent approaches. Second, I am impressed with how well positioned philosophically the Journal was to pursue range management science. It was intellectually equipped as well, at least to the extent that it published evidence of some authors, scientists, and managers intellectually wrestling not only with experimental methods, but also with conceptual tools. The road ahead, if unmapped, was open. But too little conceptual research was published in subsequent years. The Journal, in its essential editorial philosophy, did not follow the route from an integrative management art directly toward an integrative management science. Instead, the Journal, with plenty of justification, but arguably expensive consequences, took a

\section{Detour.}

Among the early papers in the Journal of Range Management, some were mensural in character, reporting and discussing original data, and were, for the time, relatively quantitative. Over the next 5 decades, papers of this kind would steadily become the most numerically important kind of paper in the Journal of Range Management. Many of these papers reported purely empirical studies, with no clear theoretical bases or defined roles in model validation. These papers reported data. Often such papers were of only local or regional interest, notwithstanding attempts by the authors to justify publishing them in a international journal like the Journal of Range Management by asserting, sometimes in the hasty closing paragraphs, the papers' general applicability. Over time, the predominance of papers of this kind in the Journal of Range Management has given the Journal the flavor of a journal of experimental science. This experimental character, combined with the preeminence of the Journal as a scientific outlet for range science, has contributed significantly to the identity of range science as a specialized experimental science, rather than as antegrated management science. The character of the papers defined the Journal, and the Journal, directly or indirectly, largely defined the science. So with the Journal of Range Management as its vehicle, range science, on its trip from a management art to a management science, has taken, more or less, a fifty-year detour.
Justifying the trip has been easy enough. In 1948, both the quantity and quality of basic information on rangelands systems must have seemed, as it still does, hopelessly inadequate. Reductionist experimental research of the kind that had developed technical sciences such as agronomy, forestry and animal sciences seemed the logical way to proceed. Many of the scientists that were to contribute to the nascent range science had technical, experimental training in these related sciences. From the viewpoint of the Editorial Board of the Journal, fundamentally sound experimental research must have seemed the best means to establish the credibility of both the Journal and of the new range science. Experimental science was, after all, real science, as opposed to management science that often involve concepts and models, and that was, in the minds of some, not real science. Lagging agronomy, forestry and animal sciences in technical, experimental science by what must have seemed decades, range science was, apparently, very late.

The subsequent development of a largely experimental range science has worked well enough in some ways. We have learned much about some basic variables related to rangelands. At least 2 generations of scientists have had successful careers conducting this research, which continues today.

But from the vantage ground of 2004, the fifty-year detour to develop an experimental range science, although hardly wasted, has been expensive. Some of the published papers of the past have had little lasting value, or no lasting value. In some cases, reductionist empirical data, bankrupted by theoretical inadequacy, has proven useless in validation work, or in other systems applications. Much field research in, for example, grazing management, has been not only costly, but has been rendered meaningless by the multiple confounded and uncontrolled variables (Scarnecchia 1988) typical in such studies. In general, much of the experimental research of these years could have been improved, and would have had more lasting value had it been conducted within a management science philosophy.

Most importantly, the detour has cost time. By following an overly empirical route from management art to management science by way of experimental science, development of range management science as a multi-objective, multi-variable, management science of land, animals and people has been critically delayed. The delayed development of the natural identity of range management science as an integrative management science rather than a technical, experimental science has contributed significantly to the recent and ongoing weak identity of range science (Scarnecchia 1995, 2003), and to its current political misfortunes.

I find little evidence beyond the diverse subject matter of the early range management textbooks that range management was widely viewed, at least in a formal philosophical sense, as an integrative profession before the 1950's. Sampson (1952) described range management as a "broad field" whose applications "leans on many sciences," and pictured it graphically as a central management activity within a wheel of integrated organisms, elements, and disciplines.

The formal concept of range science as an integrative science appeared in the 1970's. The third edition of Range Management (Stoddart et al. 1976), published in the midst of the modeling euphoria of the 1970's, described range science as a central science among supporting sciences.

If the subsequent publication record is an indication, the Journal of Range Management has had little interest in this integrative philosphy of range science, and the predominance of experimental research has continued. Publication of the conceptual components of management science research in the Journal has continued to languish, and if political and economic fortunes of range science are indicators, now we are very late. Range management science needs a plan, and the Journal of Range Management is positioned to provide leadership in the development of that plan. But before designing a publication philosophy and publication plan for the Journal of Range Management, we need to examine

\section{The Kinds of Papers the Journal of Range Management Currently Publishes.}

According to the September 2003 issue, the Journal of Range Management currently accepts the following kinds of manuscripts.

"Journal Articles report original findings in plant physiology, animal nutrition, ecology, economics, hydrology, wildlife habitat, methodology, taxonomy, grazing management, soils, land reclamation (reseeding), and range improvements (fire, mechanical, chemical). Technical Notes are short articles (usually less than 2 printed pages) reporting unique apparatus and experimental techniques. By invitation of 
the Editorial Board, a Review or Synthesis Paper may be printed in the Journal. Viewpoint Articles or Research Observations discussing opinion or philosophical concepts regarding topical material or observational data are acceptable. Such articles are identified by the word viewpoint or observations in the title."

The content of a typical issue of the Journal today reflects the descriptions in this paragraph. Several features, at least, are noteworthy.

First, the description of journal articles implies that for a paper to qualify as a journal article, it must have original findings, which has generally meant original data. This requirement for original data favors experimental research over theoretical or other conceptual research. The description excludes conceptual, theoretical or philosophical papers essential in management science research.

Second, the list of supporting areas from which the Journal accepts even original findings is limited, and in some cases, outdated. The supporting areas listed, (plant physiology, etc.) are historically the main areas of experimental, mensural science that have contributed to the Journal, but a broadened concept of range management science involves other, nontraditional areas of research. Some of these peripheral areas are where significant research money and resulting manuscripts are found today.

Third, conceptual papers, theoretical papers, philosophical papers, in fact, any manuscripts lacking data are currently relegated to classification as viewpoint articles, regardless of whether they are simply opinionated discussions of issues or are formal management science involving such matters as, for example, concept design, theory development, or theoretical modeling.

To make the Journal of Range Management a journal of integrated management science better suited to both serve and identify a science for the new century, these submission criteria need to be revisited, and revised. To accomplish the revisitation and revision, this paper follows a simple management science protocol beginning with

\section{Goals and Objectives.}

Two goals of this paper are to design the essential features of (1) a publication philosophy and (2) a publication plan for the Journal of Range Management for consideration by the Editorial Board or JRM Steering Committee. Design implies objectives, and the objectives here are to address recent, current and future challenges from the environment in which the Journal operates. The objectives of the plan outlined here are to:

1. Emphasize the essential importance of creative ideas rather than only data to range management science, and the importance of design research involving concepts, theories, and other manmade tools to the multiple-objective, multiple-efficiency challenges of the future,

2. Recognize the character of range management science as a management science of linkages between basic sciences and applications, and of communication in several senses,

3. Broaden the Journal to be more inclusive of widely diverse research in areas of land- and people-related management science historically outside of mainstream range science, and in the process, make its content more compatible with a name such as the Journal of Range Management Science.

4. Position the Journal of Range Management to take advantage of the changing character of research funding and consequent publications likely to be produced within range management science,

5. Encourage the kind of content in the Journal that reflects a strengthened, future-oriented vision of the identity of range management science as an inclusive management science involving both conceptual science and experimental science.

To achieve the preceding objectives, this paper offers the following

\section{Recommendations.}

The Editorial Board or JRM Steering Committee should revisit the editorial philosophy and publication categories of the Journal of Range Management. When the kinds of publications acceptable to the Journal are reviewed, the following matters related to each kind should at least be considered.

The category Journal Article should be retained to include original experimental research. The list of subject areas in which original research will be considered should either be expanded to include some other areas, or preferably, generalized, broadened and shortened to include a wide diversity of research in nontraditional areas, including, for example, rural sociology, resource conservation, land use, etc. The name journal article should not be abandoned in favor of research article or research paper, because such names could imply that non-experimental research is not research.

The category Technical Note should be broadened to include not only unique apparatus and experimental techniques, but also abstract analytical techniques, including, among others, conceptual and mathematical ones.

Review Papers should be eliminated from the publication plan.

Research Observation as a classification should be retained in the publication plan and be reserved for urgent or unrepeatable (not simply unrepeated, but not urgent) results of experimental research. This classification, which might also be termed a research note, should be minimized in the publication plan.

The category of Viewpoint Article should be reexamined, and narrowed in meaning to papers containing largely matters of personal judgment or evaluation related to the broad scientific content of the journal. These articles usually have high readability, and if such papers address substantive, technical matters, they should be included in the Journal's publication plan. Classification of a paper as a viewpoint article should not exempt authors from analytical rigor.

Comment Papers that are a critique of another individual paper published in the Journal of Range Management should continue to be acceptable to the Journal. Comment papers should be judged on technical and analytical merit, and on their value and interest to the Journal's readers. An author or authors whose paper is the object of an accepted comment paper should be allowed to submit a Response Paper. Response papers too should be judged on their technical and analytical merit, and on their value and interest to the Journal's readers. As long as comment and response papers have technical merit, and are likely to stimulate interest in scientific discussion, these papers should be included as numerically minor but highly visible elements of the publication plan.

Other than book reviews, which are addressed elsewhere (Scarnecchia 2004), the only other class of manuscripts that the Journal of Range Management currently publishes, and the one that needs most examination, is the

\section{Synthesis Paper.}

The Editorial Board or JRM Steering Committee should examine and define the category of Synthesis Paper. The concept of this category needs to be formalized, and the role of synthesis papers within the 
publication philosophy and publication plan of the Journal should be reevaluated. This evaluation process should be strategic in seeking a working definition of a synthesis paper that encourages creative development of range management science.

Exploration of the etymology of the word synthesis is a meritorious but limited place to start. The word synthesis is derived from the Greek by way of Latin from synthithenai [syn (together) + tithenai to place)] (Reader's Digest 1967). A typical definition of synthesis, from the same source as the preceding etymology, is the combination of separate elements into $a$ whole. The implication here is that synergy exists and that the synthetic product, the whole, is, by some measure, of greater significance than the sum of the component parts. Jan Smuts (1926) characterized this concept as the essence of the philosophy of holism, and holism has long and increasingly been recognized as a hugely important principle operating in natural systems.

More recently, the word synthetic has come to mean a man-made product. Range management science, as a man-made science to analyze and communicate matters related to natural systems, is a synthetic science, in several senses and on a number of analytical scales (Scarnecchia 2003). Creative experimental research unfailingly involves considerable synthesis too. Art, as a concept, is generally a product of synthesis. And in some sense, any writing is a product of synthesis by the author. Obviously the matter of defining a synthesis paper for the Journal of Range Management requires some judgment.

Working from the adjective synthetic, if we define a synthesis paper as a paper that includes considerable formal, synthetic analysis other than statistical analysis and explanation of data, we have defined a broad category of papers including papers which would be thought of as conceptual, theoretical, systematic, or philosophical. Under this definition, manuscripts describing experimental research that contain significant synthetic analyses beyond statistics, including experimental studies significantly directed at validation of theories or other models, would be hybrid synthesis papers. This hybrid subclass of synthesis papers has always been represented in the Journal, mostly because of frequent if inconsistent editorial insistence that in order to publish ideas, authors had better have data, and viceversa.
Submission of synthesis papers that would be thought of as largely conceptual, theoretical, systematic or philosophical would be significantly encouraged by this redesigned classification of manuscripts. These papers would no longer be relegated to pseudo-science status as viewpoint articles. That none of the 18 most influential articles in the history of the Journal of Range Management mentioned by McClaran (2000) was a viewpoint article, although hardly evidential, is worth noting. More interestingly, the 4 early articles mentioned previously contained few or no data, and under the current manuscript classification, would almost certainly be labeled viewpoint articles. One can't help wonder if the 3 that made McClaran's list would have done so had they been labeled viewpoint articles.

To promote the development of range science as a management science, this broad class of synthesis papers should be placed on the list of publications acceptable to the Journal with status equal to a journal article. This approach will increase the demands on the Editorial Board to evaluate diverse ideas and papers. But publication of creative management science manuscripts in this category will be essential to reroute range science back on the road to a management science capable of addressing management problems of multiple objectives, variables, and efficiencies. In this broadened concept of a synthesis paper, such papers would no longer need to be specifically invited by the Editorial Board; instead, authors of such papers would find the Journal's editorial submission environment

\section{Generally More Inviting.}

The Editorial Board or JRM Steering Committee could still contact authors to elicit an Invited Paper in any category of manuscript recommended in this paper. But the expanded interest by the Journal in diverse synthesis papers would be an open invitation to a broader range of papers, wider readership of the Journal of Range Management, and a more diverse membership in the Society for Range Management. The editorial plan outlined in this paper would put the Journal of Range Management on course as an institutional force for innovation, and as the energetic flagship publication of a Society for Range Management prepared to publish creative, diverse, range management science to deal with the complex challenges ahead.

\section{Literature Cited}

Campbell, Robert S. 1948. Milestones in range management. J. Range Manage. 1:4-8.

Dyksterhuis, E.J. 1949. Condition and management of range land based on quantitative ecology. J. Range Manage. 2:104-115.

Humphrey, R.R. 1949. Field comments on the range condition method of forage survey. 2:1-10.

McClaran, M.E. 2000. Viewpoint: Selecting the 5 most important papers in the first 50 years of the Journal of Range Management. 53:250-254.

Reader's Digest. 1967. The Reader's Digest great encyclopedic dictionary. The Reader's Digest Assoc., Pleasantville, N.Y.

Roach, M. E. 1950. Estimating perennial grass utilization on semidesert cattle ranges by percentages of ungrazed plants. 3:182-185.

Sampson, A.W. 1952. Range management. Publisher John Wiley and Sons. 570 p.

Scarnecchia, D. L. 1988. Minimizing confounding in case studies of agricultural systems. Agr. Syst. 26:89-97.

Scarnecchia, D. L. 1995. The rangeland condition concept and range science's search for identity. J. Range Manage. 48:181-186.

Scarnecchia, D. L. 2003. Viewpoint: Empowering diversity: Envisioning, designing and developing range management science. J. Range Manage. 56:558-569.

Scarnecchia, D. L. 2004. Viewpoint: Writing book reviews for the Journal of Range Management and Rangelands. J. Range Manage. (In press).

Smuts, J. 1926. Evolution and holism. The Macmillan Company. 362 p.

Stoddart, L. A., A. D. Smith, and T. Box. 1976. Range management. $3^{\text {rd }}$ ed. McGrawHill, New York. 532 p. 